\title{
4R Nutrient Management in Sugarcane- An Overview
}

\author{
R. Mahesh ${ }^{1}$ and Gangadhar Nanda ${ }^{2 *}$ \\ ${ }^{1}$ Agronomy and Soil Science Unit, Central Sericultural Research and Training Institute, \\ Berhampore-742 101, West Bengal, India \\ ${ }^{2}$ Animal Production Research Institute, Dr. Rajendra Prasad Central Agricultural University, \\ Pusa (Samastipur)-848 125, Bihar, India \\ *Corresponding author
}

\section{A B S T R A C T}

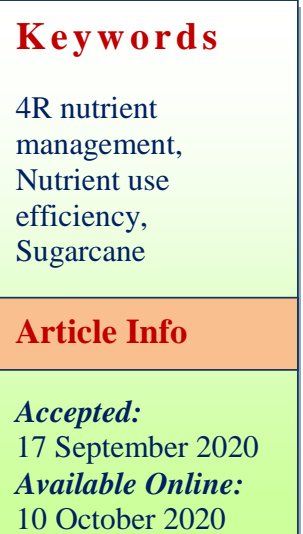

\section{Introduction}

Productivity of crops depends on the available nutrient status of the soil (Yadav and Prasad, 1992). Agricultural development has provided much evidence that adequate supply of nutrients through chemical fertilizer is the most efficient measure for increasing the yield and quality of crops. It is reported that crop yields have increased by at least 30 to $50 \%$ as a result of fertilization at global scale (Stewart et al., 2005). Among the various crops, sugarcane is a heavy feeder crop and requires very large quantity of nutrients $(\mathrm{N}$,
$\mathrm{P}_{2} \mathrm{O}_{5}$ and $\mathrm{K}_{2} \mathrm{O}$ ) which must be applied through fertilizers to obtain optimum yield on sustainable basis. In India, most of the farmers apply more fertilizer at limited splits through broadcasting on surface soil which leads to heavy loss of nitrogen through volatilization and denitrification and fixation of $\mathrm{P}$ and $\mathrm{K}$ in the soil ultimately resulting in reduced nutrient use efficiency (NUE). Such practice is very common among sugarcane farmers in India, leading to lower yield and poor quality of produce which in turn impacts farmer income and environmental pollution. With a growing demand for sugarcane, there 
is a need for efficient fertilizer management practice to achieve sustainable profit without any detrimental impact on the environment.

4R nutrient stewardship approach enables proper utilization of applied fertilizers by applying right fertilizers to match with crop demand during different crop growth period at the right spot. This approach is at the core of precision nutrient management. Before making a fertilizer application decision in any crop, farmers should have knowledge and awareness about fertilization programme viz., what type of fertilizer to apply, how much to apply, when to apply, how to apply and where to apply. Experimental evidences have shown that precision management of nutrients through right source, rate, time and place can significantly increase crop productivity and reduce environmental footprint of agricultural nutrients (Sapkota et al., 2014). Subsurface drip fertigation has been proved as an efficient nutrient management approach for improving yield, profit and nutrient use efficiency of sugarcane. This article overviews the impact of 4R nutrient stewardship based NPK application on sugarcane crop in India.

\section{R nutrient management in sugarcane}

Right source: matching the fertilizer types to crop needs

Plants absorb the essential nutrients through their root systems from the soil in various forms viz., nitrate $\left(\mathrm{NO}_{3}{ }^{-}\right)$and ammonium $\left(\mathrm{NH}_{4}{ }^{+}\right)$for $\mathrm{N}$, primary $\left(\mathrm{H}_{2} \mathrm{PO}_{4}{ }^{-}\right)$or secondary $\left(\mathrm{HPO}_{4}{ }^{2-}\right)$ orthophosphate for $\mathrm{P}$ and elemental form $\left(\mathrm{K}^{+}\right)$for $\mathrm{K}$. Fertilizer application is the common practice to supply NPK to meet out the nutrient demand of the crop. Accordingly, selecting the right source of fertilizer is imperative to supply the plant essential nutrients as per the crop. Fertigation is for the most efficient way of nutrient application
(Bar-Yosef, 1991) and provides an excellent opportunity to maximize the crop productivity and minimize environmental pollution (Hagin et al., 2002) by reducing fertilizer needs and improving NUE. It is awfully important to select fertilizers depending upon crop needs and suitability to fertigation. Before selecting fertilizer for fertigation, the following factors should be considered viz., plant nutritional requirements, solubility, nutrient available form, nutrient content and compatibility with other fertilizers. Water soluble fertilizers are very much suitable for fertigation because they are made up of combinations of available forms of nutrients and are fully soluble in nature. So, when the fertilizer dissolves in water, the nutrients can be immediately available for plant uptake (Biswas, 2010). Nutrient content, available form, solubility, $\mathrm{pH}$ and insoluble percentages of selected water soluble fertilizers are given in Table 1. For efficient nutrient management through fertigation with $4 \mathrm{R}$ nutrient stewardship, it is mandatory to select fertilizer source in which the essential plant nutrients are in readily available forms and fully soluble in water.

There are several commercial nitrogen, phosphorus and potassium fertilisers that can be used for fertigation in sugarcane. Various research works have confirmed that the following fertilizers grades viz., Urea $(46 \%$ $\mathrm{N}$ ), as the primary source of $\mathrm{N}$ (based on cost), MAP-Mono ammonium phosphate $\left(12 \% \mathrm{~N}\right.$ and $\left.61 \% \mathrm{P}_{2} \mathrm{O}_{5}\right)$ and All $19(19 \% \mathrm{~N}$; $19 \% \mathrm{P}_{2} \mathrm{O}_{5}$ and $19 \% \quad \mathrm{~K}_{2} \mathrm{O}$ ) for $\mathrm{P}$ source and $\mathrm{KNO}_{3}\left(13 \% \mathrm{~N}\right.$ and $\left.45 \% \mathrm{~K}_{2} \mathrm{O}\right)$ for $\mathrm{K}$ source are most suitable commercial water soluble fertilizers (WSF) for fertigation in sugarcane in order to get higher cane yield and improved NUE. Mahesh (2015) studied the effect of fertigation with WSF (Urea, All 19, MAP and $\mathrm{KNO}_{3}$ ) and normal fertilizers (NF) (urea, diammonium phosphate and muriate of potash) on cane yield and NUE of sugarcane under subsurface drip irrigation system (Table 
2). This experimental conducted at Tamil Nadu Agricultural University, Coimbatore, India. The revised soil test based crop response nutrient recommendation of 300:100:200 kg N, $\mathrm{P}_{2} \mathrm{O}_{5}$ and $\mathrm{K}_{2} \mathrm{O}$ ha $^{-1}$ was used for this experimentation. Fertigation was scheduled at 7 days intervals starting from $2^{\text {nd }}$ week to $34^{\text {th }}$ week after planting. Results revealed that WSF outperformed and significantly improved the number of millable canes by $24.34 \%$, individual cane weight by $34.5 \%$ and cane yield by $34 \%$ compared to NF source under subsurface drip irrigation. Further, the results of the experiment indicated that fertigation through WSF increased NUE ( $\mathrm{kg}$ of cane per $\mathrm{kg}$ of NPK applied) by $29.69 \%$ compared to NF. Similarly, use of WSF \{Urea $(46 \% \mathrm{~N})$, Poly feed $\left(20 \% \mathrm{~N} ; 10 \% \mathrm{P}_{2} \mathrm{O}_{5}\right.$ and $\left.10 \% \mathrm{~K}_{2} \mathrm{O}\right)$, MAP $\left(12 \% \mathrm{~N}\right.$ and $\left.61 \% \mathrm{P}_{2} \mathrm{O}_{5}\right)$ and SOP $\left(50 \% \mathrm{~K}_{2} \mathrm{O}\right.$ and $18 \% \mathrm{~S})\}$ through drip irrigation could increase plant height, no. of internodes, girth of internodes, individual cane weight, leaf area and cane yield of suru sugarcane by 2.72 , $3.99,2.14,9.46,5.66 \& 8.18 \%$ respectively compared to normal fertilizer source (Urea, SSP and MOP) (Chaudhari et al., 2010). Similarly, fertigation of water soluble fertilizers (WSF) significantly increased cane yield to the extent of $8.2 \%$ than that of straight fertilizers (SF) (Bangar and Chaudhari, 2004).

\section{Right rate- Matching amount of nutrient as per crop requirement}

The law of diminishing returns by Mitscherlich (1909) indicates that as the dose of nutrient increases, the growth rate and yield increase but with diminishing rates. Therefore, application of recommended nutrients in different split doses to coincide with nutrients need of crop at different developmental periods is essential to obtain higher cane yield and nutrient uptake. To achieve targeted yield, it is essential to have knowledge on quantity of nutrients (right rate) to be applied through fertigation. The concept of applying the right rate is providing adequate nutrients to meet crop production and quality goals (Hochmuth et al., 2014). Sometimes, over fertilization may cause toxicity to the crop as well as pollute the ground water and environment. Based on the information of the available nutrients in soil by soil testing and nutrient uptake by the crop through plant analysis, the actual nutrient requirement of the crop could be identified (Harold and Reetz, 2016).

Sugarcane needs higher quantity of NPK nutrients for better performance with respect to yield and quality. According to Shukla et al., (2017) sugarcane require an average 208 $\mathrm{kg}$ of $\mathrm{N}, 53 \mathrm{~kg}$ of $\mathrm{P}, 280 \mathrm{~kg}$ of $\mathrm{K}$ to produce 100 tonnes of cane yield. But the nutrient uptake varies considerably depending on the climate, varieties and available nutrient status in soil and agronomic management practices followed. It is estimated that for achieving the targeted yield of 200 tonnes per hectare, a nutrients dose (ND) of $\mathrm{N}, \mathrm{P}_{2} \mathrm{O}_{5}, \mathrm{~K}_{2} \mathrm{O}=$ $300: 100: 200 \mathrm{~kg} \mathrm{ha}^{-1}$ would be required under Indian condition (Crop Production Guide, 2020).

The response of sugarcane to different fertilizer rates $(100 \%$ ND- $300 \mathrm{~kg} \mathrm{~N}, 100 \mathrm{~kg}$ $\mathrm{P}_{2} \mathrm{O}_{5}$ and $200 \mathrm{~kg} \mathrm{~K} 2 \mathrm{O}$ per ha and $75 \%$ ND$225 \mathrm{~kg} \mathrm{~N}, 75 \mathrm{~kg} \mathrm{P}_{2} \mathrm{O}_{5}$ and $150 \mathrm{~kg} \mathrm{~K} \mathrm{O}_{2} \mathrm{O}$ per ha) were studied under SSDF (Table 3) and the result revealed that significantly higher plant growth and yield parameters were registered under $100 \%$ ND over $75 \%$ ND. Further, significantly higher cane yield (185.65 t/ha) was registered with $100 \%$ ND than $75 \%$ ND (164.77 t/ha). Similarly, increasing nutrient dose from 75 to $125 \%$ increased yield attributes (number of millable canes, number of internodes, internodes girth and cane weight) and cane and sugar yields (Mahadkar et al., 2005). 
Table.1 Nutrient content, available form, solubility, $\mathrm{pH}$ and insoluble percentages of water soluble fertilizers

\begin{tabular}{|c|c|c|c|c|c|c|c|}
\hline Nutrient & $\begin{array}{c}\text { Water } \\
\text { soluble } \\
\text { fertilizer }\end{array}$ & $\begin{array}{l}\text { Nutrient } \\
\text { content }\end{array}$ & $\begin{array}{c}\text { Nutrient } \\
\text { available } \\
\text { form }\end{array}$ & $\begin{array}{c}\text { Solubility } \\
\text { at } 20^{\circ} \mathrm{C} \\
(\mathrm{kg} / 100 \text { lit })\end{array}$ & pH & $\begin{array}{l}\text { Time to } \\
\text { dissolve } \\
\text { (min) }\end{array}$ & $\begin{array}{c}\text { Insolubles } \\
(\%)\end{array}$ \\
\hline $\mathbf{N}$ & Urea & $46: 00: 00$ & Urea-N & 110 & 9.5 & 20 & Negligible \\
\hline \multirow[t]{2}{*}{$\mathbf{P}$} & MAP & $12: 61: 00$ & $\begin{array}{c}\mathrm{NH}_{4}^{+} \\
\mathrm{H}_{2} \mathrm{PO}_{4}^{-}\end{array}$ & 40 & 4.5 & 20 & 11 \\
\hline & All 19 & $19: 19: 19$ & $\begin{array}{c}\text { Urea-N } \\
\mathrm{NO}_{3}^{-} \\
\mathrm{NH}_{4}^{+}\end{array}$ & - & - & - & - \\
\hline \multirow[t]{2}{*}{$\mathbf{K}$} & $\mathrm{KNO}_{3}$ & $13: 00: 45$ & $\begin{array}{c}\mathrm{NO}_{3}^{-} \\
\mathrm{K}^{+}\end{array}$ & 31 & 10.8 & 3 & 0.1 \\
\hline & SOP & $\begin{array}{c}00: 00: 50 \\
18 \% \mathrm{~S}\end{array}$ & $\begin{array}{c}\mathrm{K}^{+} \\
\mathrm{SO}_{4}^{2-}\end{array}$ & 11 & $8.5-9.5$ & 5 & $0.5-4$ \\
\hline
\end{tabular}

Table.2 Effect of WSF and NF on yield and NUE in sugarcane under fertigation

\begin{tabular}{|c|c|c|c|c|c|c|c|}
\hline $\begin{array}{l}\text { Source of } \\
\text { fertilizers }\end{array}$ & $\begin{array}{c}\text { NMC } \\
(\text { lakhs } \\
\left.\text { ha' }^{-1}\right)\end{array}$ & $\begin{array}{l}\text { Millable } \\
\text { cane } \\
\text { length } \\
(\mathrm{cm})\end{array}$ & $\begin{array}{c}\text { No of } \\
\text { internodes }\end{array}$ & $\begin{array}{c}\text { Cane } \\
\text { weight } \\
\left(\mathrm{kg} \mathrm{cane}^{-1}\right)\end{array}$ & $\begin{array}{c}\text { Cane } \\
\text { yield } \\
\left(\mathbf{t ~ h a}^{-1}\right)\end{array}$ & $\begin{array}{c}\text { Sugar } \\
\text { yield } \\
\left(\begin{array}{c}t \text { ha- } \\
1\end{array}\right)\end{array}$ & $\begin{array}{c}\text { NUE } \\
\text { (kg/kg } \\
\text { of NPK } \\
\text { applied) }\end{array}$ \\
\hline WSF & 1.31 & 342 & 29.90 & 1.90 & 185.69 & 25.31 & 309.45 \\
\hline NF & 1.00 & 263 & 24.76 & 1.55 & 143.16 & 16.43 & 238.6 \\
\hline
\end{tabular}

Source: Mahesh and Asokaraja (2015)

WSF: Urea, MAP, All 19 and $\mathrm{KNO}_{3}$

NF: Urea, DAP and MOP;

Table.3 Effect of fertigation levels on yield and NUE in sugarcane under fertigation

\begin{tabular}{|c|c|c|c|c|c|c|c|}
\hline $\begin{array}{l}\text { Fertilizer } \\
\text { dose } \\
\left(\mathrm{N}: \mathrm{P}_{2} \mathrm{O}_{5}:\right. \\
\mathrm{K}_{2} \mathrm{O} \text { kg/ha) }\end{array}$ & $\begin{array}{l}\text { NMC } \\
\text { (lakhs } \\
\text { ha }^{-1} \text { ) }\end{array}$ & $\begin{array}{l}\text { Millable } \\
\text { cane } \\
\text { length } \\
\text { (m) }\end{array}$ & $\begin{array}{l}\text { No of } \\
\text { internodes }\end{array}$ & $\begin{array}{l}\text { cane } \\
\text { weight }(\mathrm{kg} \\
\left.\text { cane }^{-1}\right)\end{array}$ & $\begin{array}{l}\text { Cane } \\
\text { yield } \\
\left(\mathrm{t} \mathrm{ha}^{-1}\right)\end{array}$ & $\begin{array}{l}\text { Sugar } \\
\text { yield } \\
\left(\mathbf{t ~ h a}^{-1}\right)\end{array}$ & $\begin{array}{l}\text { NUE } \\
\text { (kg/kg } \\
\text { of NPK } \\
\text { applied) }\end{array}$ \\
\hline 300:100:200 & 1.31 & 3.42 & 29.90 & 1.90 & 185.69 & 25.31 & 309.45 \\
\hline 225:75:150 & 1.12 & 3.02 & 26.52 & 1.70 & 164.77 & 20.53 & 366.15 \\
\hline
\end{tabular}

Source: Mahesh and Asokaraja (2015) 
Table.4 4R nutrient management fertigation schedule for sugarcane

\begin{tabular}{|c|c|c|c|c|c|c|c|}
\hline \multirow{2}{*}{$\begin{array}{l}\text { Right } \\
\text { source }\end{array}$} & \multirow{2}{*}{$\begin{array}{c}\text { Right Rate } \\
\text { (kg/ha) }\end{array}$} & \multicolumn{2}{|c|}{ Right Time } & \multirow[b]{2}{*}{ Right place } & \multicolumn{3}{|c|}{ Nutrient requirements } \\
\hline & & $\begin{array}{l}\text { Stage } \\
\text { (days) }\end{array}$ & $\begin{array}{l}\text { No. of } \\
\text { times }\end{array}$ & & $\begin{array}{c}\mathrm{N} \\
\mathrm{kg} / \mathrm{ha}\end{array}$ & $\begin{array}{l}\mathrm{P}_{2} \mathrm{O}_{5} \\
\mathrm{~kg} / \mathrm{ha}\end{array}$ & $\begin{array}{c}\mathrm{K}_{2} \mathrm{O} \\
\mathrm{kg} / \mathrm{ha}\end{array}$ \\
\hline MAP & 44.30 & \multirow{4}{*}{$7-30$} & \multirow{4}{*}{3} & \multirow{20}{*}{ 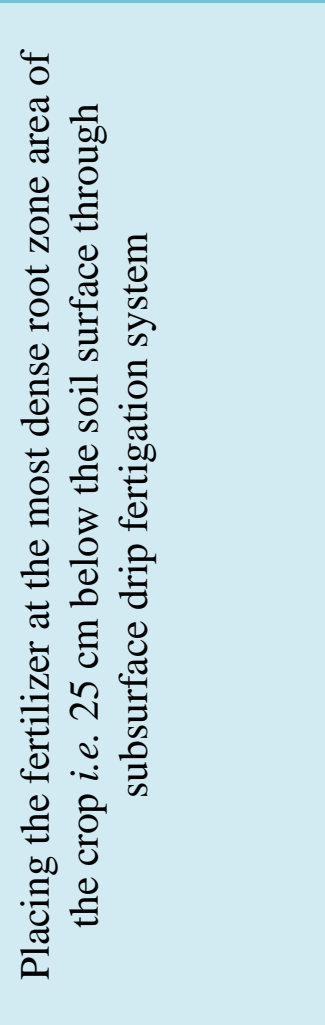 } & 45.00 & 31.90 & 10.60 \\
\hline All 19 & 25.65 & & & & & & \\
\hline $\mathrm{KNO}_{3}$ & 12.82 & & & & & & \\
\hline Urea & 72.06 & & & & & & \\
\hline MAP & 42.50 & \multirow[t]{4}{*}{$31-60$} & \multirow{4}{*}{4} & & 54.60 & 31.90 & 17.70 \\
\hline All 19 & 31.45 & & & & & & \\
\hline $\mathrm{KNO}_{3}$ & 26.19 & & & & & & \\
\hline Urea & 85.91 & & & & & & \\
\hline MAP & 22.50 & \multirow[t]{4}{*}{$61-90$} & \multirow[t]{4}{*}{4} & & 54.60 & 19.10 & 17.70 \\
\hline All 19 & 28.50 & & & & & & \\
\hline $\mathrm{KNO}_{3}$ & 27.44 & & & & & & \\
\hline Urea & 92.00 & & & & & & \\
\hline MAP & 20.00 & \multirow[t]{4}{*}{$90-120$} & \multirow[t]{4}{*}{4} & & \multirow[t]{4}{*}{60.00} & \multirow[t]{4}{*}{17.00} & \multirow[t]{4}{*}{21.30} \\
\hline All 19 & 25.35 & & & & & & \\
\hline $\mathrm{KNO}_{3}$ & 36.62 & & & & & & \\
\hline Urea & 104.40 & & & & & & \\
\hline $\mathrm{KNO}_{3}$ & 157.78 & \multirow[t]{2}{*}{$120-180$} & \multirow[t]{2}{*}{8} & & \multirow[t]{2}{*}{64.50} & \multirow[t]{2}{*}{0.00} & \multirow[t]{2}{*}{71.00} \\
\hline Urea & 97.58 & & & & & & \\
\hline $\mathrm{KNO}_{3}$ & 136.70 & \multirow[t]{2}{*}{$180-210$} & \multirow[t]{2}{*}{4} & & \multirow[t]{2}{*}{21.30} & \multirow[t]{2}{*}{0.0} & \multirow[t]{2}{*}{61.50} \\
\hline Urea & 8.32 & & & & & & \\
\hline & & & 27 & Total & 300 & 100 & 200 \\
\hline
\end{tabular}

Table.5 Effect of fertigation and soil application of fertilizers on yield and NUE in sugarcane

\begin{tabular}{|c|c|c|c|c|c|c|c|}
\hline $\begin{array}{l}\text { Fertilizer } \\
\text { placement }\end{array}$ & $\begin{array}{c}\text { Tiller } \\
\text { production } \\
(\text { No./m) }\end{array}$ & $\begin{array}{c}\text { Plant } \\
\text { height } \\
\text { (cm) }\end{array}$ & $\begin{array}{l}\text { Cane weight } \\
\left(\mathrm{kg} \mathrm{cane}^{-1}\right)\end{array}$ & $\begin{array}{l}\text { CCS } \\
(\%)\end{array}$ & $\begin{array}{c}\text { Cane } \\
\text { yield } \\
\left(\mathbf{t} \mathbf{~ h a}^{-1}\right)\end{array}$ & $\begin{array}{c}\text { Sugar } \\
\text { yield } \\
\left(\mathrm{t} \mathrm{ha}^{-1}\right)\end{array}$ & $\begin{array}{c}\text { NUE } \\
\text { (kg/kg of } \\
\text { NPK } \\
\text { applied) }\end{array}$ \\
\hline $\begin{array}{l}\text { Fertigation } \\
\text { SSDF }\end{array}$ & 21.4 & 345.1 & 2.12 & 9.77 & 193.6 & 18.91 & 344.17 \\
\hline Soil application & 11.7 & 217 & 1.28 & 7.77 & 86.8 & 6.74 & 192.88 \\
\hline
\end{tabular}

Source: Gurusamy et al., (2013)

*SSDF- sub-surface drip fertigation

Right time-providing nutrients when crop demands

The rate of nutrient application by the crops is totally based on the type, stage and need of the crops, also nutrient supplying capacity of the soil (Khan et al., 2001; Hartz and Hochmuth, 1996). Plants require different rates of nutrients over the growing season as per various physiological stages. In this 
context, applying large quantity of fertilizers in limited splits cause $\mathrm{N}$ losses by leaching and denitrification and fixation of $\mathrm{P}$ and $\mathrm{K}$ in the soil ultimately results in poor fertilizer use efficiency and pollution of environment (Dangler and Lacascio, 1990). Further, untimely fertiliser application reduces nutrient uptake as well as its efficiency (Kwong and Deville 1987). Thus, for efficient nutrient management, supply of nutrients should be adjusted to counterpart with need of the crop at different times during growing periods. Nutrient accumulation patterns could be observed by doing tissue analysis at regular intervals, at the same time soil analysis could help to understand the nutrient depletion patterns in the soil and capacity of soil to supply nutrients for plant uptake. With this information, it can be possible to quantify the nutrients needs by the plant at different times during growing periods (help to decide time and frequency of fertilizer application). Hence, it is essential that timing of fertilizer application should meet with nutrient demands of the crop (nutrient uptake pattern) for maximizing fertilizer use efficiency.

Rate and pattern of nutrient uptake by the sugarcane crop is mainly decided by stage of the crop, soil moisture conditions, forms of nutrients, available nutrient status of the soil, climatic factors and variety used. The uptake of nutrients (NPK) varies considerably with growth stage of sugarcane. $\mathrm{N}, \mathrm{P}$ and $\mathrm{K}$ for sugarcane cane is usually applied in split doses under drip fertigation. The total $\mathrm{N}, \mathrm{P}$ and $\mathrm{K}$ can be given in 27 splits starting from 7-210 days of planting. Out of 100\% RDF (N, $\left.\mathrm{P}_{2} \mathrm{O}_{5}, \mathrm{~K}_{2} \mathrm{O}=300: 100: 200 \mathrm{~kg} \mathrm{ha}^{-1}\right)$, the splits can be given as: $15 \% \mathrm{~N}, 31.90 \% \mathrm{P}_{2} \mathrm{O}_{5}$ and $5.32 \% \mathrm{~K}_{2} \mathrm{O}$ at germination stage (7-30 days-3 splits), $18.20 \% \mathrm{~N}, 31.90 \% \mathrm{P}_{2} \mathrm{O}_{5}$ and $8.88 \%$ $\mathrm{K}_{2} \mathrm{O}$ at early tillering stage (31-60 days-4 splits), $18.20 \% \mathrm{~N}, 19.14 \% \mathrm{P}_{2} \mathrm{O}_{5}$ and $8.88 \%$ $\mathrm{K}_{2} \mathrm{O}$ at peak tillering stage (61-90 days-4 splits), $20 \% \mathrm{~N}, 17.02 \% \mathrm{P}_{2} \mathrm{O}_{5}$ and $10.65 \% \mathrm{~K}_{2} \mathrm{O}$ at canopy establishment stage (91-120 days-4 splits), $21.80 \% \mathrm{~N}, 0 \% \mathrm{P}_{2} \mathrm{O}_{5}$ and $35.50 \% \mathrm{~K}_{2} \mathrm{O}$ at grand growth stage (121-180 days-8 splits) and $7.30 \% \mathrm{~N}, 0 \% \mathrm{P}_{2} \mathrm{O}_{5}$ and $30.76 \% \mathrm{~K}_{2} \mathrm{O}$ at maturity stage (181-210 days-4 splits). The nutrient requirement of sugarcane at different growth stages have been worked and presented in Table 4. Fertigation of $100 \%$ recommended NPK through water soluble fertilizers in 20 equal splits at weekly interval improved the cane yield by $32.50 \%$ in comparison to soil fertilization of straight fertilizers with surface irrigation (Bangar and Chaudhari, 2001). However, study of Yadav et al., (2015) indicated that fertigation of recommend nutrients either in 9 splits at 20 days interval or 12 splits at 15 days interval was more effective in enhancing cane yield than surface irrigation with soil fertilization with corresponding increments in cane yield by $25.34 \%$ and $24.33 \%$, respectively. Similarly, drip fertigation at $100 \%$ RDF with WSF (urea, urea phosphate and MOP) increased the cane yield by $33.86 \%$ and $40.72 \%$ when applied at 12 and 26 splits, respectively over surface irrigation with soil application of $100 \%$ RDF with NF (Pawar et al., 2014).

\section{Right place - keeping nutrients where crops can use them}

The proper placement of fertiliser is the key for better nutrient utilization and avoidance of nutrient losses from the soil. Under soil fertilization through broadcasting method, applied nitrogen fertilizer in soil is not fully utilized by the plants due to various losses viz., leaching, run-off and volatilization losses as well as nutrient fixation in soil. In order to maximize the NUE, it is essential to place the nutrients where the plants can absorb more. Further, it can be assumed that placing the fertilizers at the right location could help the roots to absorb more nutrients for the entire cropping season. Generally, placement of 
fertilizers either in the most concentrated root zone or $20 \mathrm{~cm}$ deep in the subsoil layer is considered as best spot to place fertilizers in order to maximize their utilization by the plants. Nutrients are mainly absorbed by the roots, therefore spreading fertilizers around the root zone could help to improve the probability of nutrients absorption by the plants. Fertigation is the innovative tool to apply the fertilizer more efficiently (Kafkafi and Tarchitzky, 2011). Moreover, subsurface drip fertigation could facilitate direct delivery of the nutrients at the intensive root zone below the soil surface thus improving fertilizer use efficiency by reducing different losses.

Subsurface drip fertigation is superior technology for efficient nutrient management in sugarcane. It offers an opportunity for placing fertilizer nutrients along with irrigation water at the right location below the soil surface $(20-25 \mathrm{~cm})$, using buried drip tapes (Ruskin, 2000; ASAE, 2001; Lamm, 2009). It ensures that nutrients are suppllied as per the need of crop (nutrient applied vs. nutrients removed by crop) at the specific location thereby results in higher crop yields and quality (He and Kang, 2000). This improves nutrient use efficiency; minimize leaching and volatilization losses as well as ground water contamination. The effect of subsurface drip fertigation and soil application of fertilizer in sugarcane (Gurusamy et al., 2013) is presented in Table 5. Dhotre et al., (2008) registered higher cane yield of $134.9 \mathrm{t} \mathrm{ha}^{-1}$ under subsurface drip irrigation (SSDI) compared to surface irrigation (65 t ha $\left.{ }^{-1}\right)$. Similarly, SSDF at $100 \%$ $\mathrm{RDF}$ at $1.8 \mathrm{~m}$ lateral spacing with double side planting increased cane yield and sugar yield by $77.08 \%$ and $98.18 \%$, respectively over surface irrigation with soil application of 100\% RDF (Mahesh et al., 2010).

In conclusion the adoption of efficient nutrient management is extremely important not only to improve crop yield on sustainable basis but also to enhance nutrient use efficiency for environmental protection. Fertigation is the right option for supplying water and nutrients to the high biomass producing crop like sugarcane. Since, it will facilitate maximum nutrient uptake and in turn the yield; ultimately maximizing the nutrient use efficiency. Especially, subsurface drip fertigation has the capability to deliver the right nutrients, each at the right quantity, at the right location and at the right stage. However, to achieve full benefits out of this technology, it is essential to educate the farmers with technical skills in the areas of fertigation system operation, fertilizers selection, time of fertigation, rate of fertigation, method and location of fertilizer placement, irrigation frequency and amount, etc. From the above discussion, it could be concluded that to achieve higher crop productivity and nutrient use efficiency in sugarcane cultivation on sustainable basis, there is a need to promote the efficient nutrient management by using $4 \mathrm{R}$ nutrient stewardship approach.

\section{References}

ASAE. 2001. ASAE Standard S526.2, JAN01, Soil and Water Terminology, ASAE, St. Joseph, Michigan.

Bangar AR, Chaudhari BC. 2001. Nutrient mobility in soil, uptake, quality and yield of suru sugarcane as influenced by fertigation through drip in medium vertisols. In: Proceedings of international conference on Micro and Sprinkler Irrigation Systems, 8-10 February, Jalgaon, Maharashtra, India, pp. 480-488.

Bangar AR, Chaudhari BC. 2004. Nutrient mobility in soil, uptake, quality and yield of sugarcane as influenced by the drip fertigation in medium vertisols. Journal of Indian Society of Soil Science 52: 164-171. 
Bar-Yosef B, Martinez HJJ, Sagiv B, Levkovitch I, Markovitch I, Phene CJ. 1991. Processing tomato response to surface and subsurface drip phosphorous fertigation. Bard Project Scientific Report, Bet Dagan, pp. 175191.

Biswas BC. 2010. Fertigation in High Tech Agriculture A Success Story of A Lady Farmer. Fertiliser Marketing News 41(10): 4-8.

Chaudhari BC, Patil VN, Patel PL. 2010. Influence of liquid fertilizers through drip irrigation on growth and yield of Suru sugarcane. An Asian Journal of Soil Science 5(1): 209-211.

Crop Production Guide. 2020. Published by Tamil Nadu Agricultural University, Coimbatore. page no. 296.

Dangler JM, Locascio SJ. 1990. Yield of trickle-irrigated tomatoes as affected by time of $\mathrm{N}$ and $\mathrm{K}$ application. Journal of the American Society for Horticultural Science 115: 585-589.

Dhotre RS, Hadge SB, Rajput BK. 2008. Influence of subsurface irrigation through porous pipes on the yield and quality of sugarcane. Journal of Maharashtra Agricultural University 33: 234-237.

Gurusamy A, Mahendran PP, Krishnasamy S, Babu R. 2013. Multispecialty Water Soluble Fertilizers and Sulphur Enhances the Yield and Quality of Sugarcane under Subsurface Drip Fertigation System. International Journal of Chemical, Environmental \& Biological Sciences 1(2): 387-390.

Hagin J, Lowengart A, Sneh M. 2002. Fertigation-Fertilizer through irrigation. IPI Research Topics No: 23. A.E. Johnston. (Ed.). International Potash Institute, Basel, Switzerland.

Harold F, Reetz JR. 2016. Fertilizers and their Efficient Use. International Fertilizer Industry Association (IFA), Paris,
France.

Hartz T K, Hochmuth GJ. 1996. Fertility management of drip-irrigated vegetables. Hort Technology 6(3): 168172.

He H, Kang SZ. 2000. The economic and environmental effect of subsurface drip irrigation. The Journal of Northwest Agricultural University 28(3): 79-83.

Hochmuth G, Mylavarapu R, Hanlon E. 2014. The four Rs of fertilizer management. Univ. of Florida, Electronic Data Information Source.

Kafkafi U, Tarchitzky J. 2011. Fertigation: A Tool for Efficient Fertilizer and Water Management. IFA, Paris, France and IPI, Horgen, Switzerland. Available at https://www.ipipotash.org/uploads/udoc s/2011_ifa_fertigation.pdf

Khan MM, Shivashankar K, Farooqui AA, Krishna M, Kariyanna R, Sreerama R. 2001. Research highlights of studies on fertigation in horticultural crops. PDC, GKVK, UAS Bangalore, p 28.

Kwong KNK, Deville J. 1987. Residual fertilizer nitrogen as influenced by timing and nitrogen forms in a silty clay soil under sugarcane in Mauritius. Fertilizer research 14(3): 219-226.

Lamm FR. 2009. Managing the challenges of subsurface drip irrigation. In: Proceedings of the Irrigation Association Technical Conference, San Antonio, Texas, 2-5 ${ }^{\text {th }}$ December, Available from the Irrigation Association, Falls Church, Virginia.

Mahadkar UV, Raut RS, Shinde JB, Pawar DD, Gaikwad CB. 2005. Response of pre seasonal sugarcane to planting material, inter row spacing and fertilizer levels under drip irrigation. In: Proceedings of National Seminor on Relevance of Micro irrigation in Sugarcane, 9-10 ${ }^{\text {th }}$ February 2005, Vasantdada Sugar Institute, Pune, 
Maharashtra, India, pp. 121-130.

Mahesh R, Asoka Raja N. 2015. Influence of source of fertilizers and fertilizer levels on tillers production, shoot population, number of millable canes and yield of sugarcane under subsurface drip fertigation. Trends in Biosciences 8(4):1095-1099.

Mahesh R, Krishnasamy S, Gurusamy A, Mahendran PP. 2010. Effect of crop geometry and method of planting under subsurface drip fertigation on growth and yield of sugarcane. In: Proceedings of $9^{\text {th }}$ Joint Annual Convention of STAI $\&$ SISSTA $19^{\text {th }}-21^{\text {st }}$ August, 2010, Chennai, Tamil Nadu, pp.63-73.

Mahesh. 2015. Effect of water soluble fertilizers and normal fertilizers on yield and quality of sugarcane under surface and subsurface drip fertigation system. Ph.D Thesis. Tamil Nadu Agricultural University, Coimbatore.

Mitscherlich EA. 1909. The law of the minimum and the law of diminishing soil productivity (In German). Landwirtschafliche Jahrbuecher, 38: 537-552.

Pawar DD, Dingre SK, Durgude AG. 2014. Enhancing nutrient use and sugarcane (Saccharum officinarum) productivity with reduced cost through drip fertigation in western Maharashtra.
Indian Journal of Agricultural Sciences 84 (7): 844-849.

Ruskin R. 2000. Subsurface drip irrigation and yields. Geoflow Inc.

Sapkota TB, Majumdar K, Jat ML, Kumar A, Bishnoi DK, McDonald AJ, Pampolino M. 2014. Precision nutrient management in conservation agriculture based wheat production of Northwest India: Profitability, nutrient use efficiency and environmental footprint. Field Crops Research 155: 233-244.

Shukla SK, Sharma L, Awasthi SK, Pathak AD. 2017. Sugarcane in India: Package of practices for different Agro-climatic zones, AICRP (S) Technical Bulletin No. 1: 1-64.

Stewart WM, Dibb DW, Johnston AE, Smyth TJ. 2005. The contribution of commercial fertilizer nutrients to food production. Agronomy Journal 97: 1-6.

Yadav BS, Chouhan RPS, Bhati AS. 2015. Effect of drip irrigation and fertigation on growth and yield of sugarcane. Indian Journal of Sugarcane Technology 30(2): 67-69.

Yadav RL, Prasad SR. 1992. Conserving the organic matter content of the soil to sustain sugarcane yield. Experimental Agriculture 28: 57-62.

\section{How to cite this article:}

Mahesh, R. and Gangadhar Nanda 2020. 4R Nutrient Management in Sugarcane- An Overview. Int.J.Curr.Microbiol.App.Sci. 9(10): 2423-2431.

doi: https://doi.org/10.20546/ijcmas.2020.910.289 